BEduManageRs Journal

Borneo Educational Management and Research Journal, Vol.2, No.1, 2021

ISSN: 2747-0504

\title{
Pengaruh Perilaku Kepemimpinan, Motivasi Kerja, dan Pendidikan Terhadap Kinerja Pegawai
}

\author{
Nicodemus Sere ${ }^{1}$, Muh. Amir M², Labulan ${ }^{3}$ \\ Universitas Mulawarman \\ e-mail: $\underline{\text { doktormp@ fkip.unmul.ac.id, nurergaamir@yahoo.com, pm_labulan@yahoo.co.id }}$
}

\begin{abstract}
The purpose of this study was to determine the effect of the Leadership Behavior variable $\left(X_{1}\right)$, Work Motivation $\left(X_{2}\right)$ and Education Level $\left(X_{3}\right)$ which had a dominant effect on Employee Performance (Y) at the Mulawarman University Teacher Training and Education Faculty. The results of the study showed that based on the results of the research and analysis of the variables that affect the Leadership variable $\left(X_{1}\right)$ it has a significant effect on the Performance $(Y)$ of the Teachers and Education Faculty employees of Mulawarman University. The partial test results show that the $t$ test for Work Motivation variable $\left(X_{2}\right)$ on Performance $(Y)$ with $t$ count value of 1.668 is smaller than t table 0.260 or significance $t=1.668$ smaller than $\alpha 5 \%$. This means that the Work Motivation variable $\left(X_{2}\right)$ has a significant influence on the Performance (Y) of the Teachers' School and Mulawarman University Education staff so that the hypothesis in this study is rejected. This indicates that work motivation is one of the ways used by a leader to exercise control. Based on the results of statistical analysis showing work motivation variables on the performance productivity of the Mulawarman University Teaching and Education Faculty employees, it was pointed out that motivation had a significant and significant effect on the performance productivity of the Mulawarman University Teaching and Education Faculty employees, this shows that the higher motivation of employees to work, the the high level of performance productivity of the Mulawarman University Teacher Training and Education Faculty employees. Based on the results of statistical analysis, the educational variables have a positive and significant effect on employee performance.

The results of this study indicate that there is a positive relationship between education and the performance of the staff of the Teaching and Education Faculty of Mulawarman University so that the hypothesis in this study is universally universal.
\end{abstract}

Keywords: Leadership Behavior, Work Motivation, Education, Employee Performance Outcomes.

\section{PENDAHULUAN}

Dalam sebuah organisasi, sumber daya manusia merupakan unsur yang sangat menentukan tercapainya tujuan dengan efektif dan efisien. Perilaku dari setiap anggota organisasi dalam melaksanakan berbagai tugas merupakan pencerminan kinerja pegawai dan keefektifan suatu organisasi. Pada dasarnya, setiap anggota organisasi akan mencurahkan segenap kemampuan dan daya serta pikirannya untuk meningkatkan kinerja yang sering disebut dengan istilah kinerja para karyawan atau pegawai. Kinerja merupakan proses tingkah laku seseorang sehingga ia menghasilkan sesuatu yang menjadi tujuan dari pekerjaannya. Perbedaan kinerja antara seseorang dengan lainnya di dalam situasi kerja adalah karena perbedaan karakteristik dari individu. Di samping, itu seseorang dapat menghasilkan kinerja yang berbeda di dalam situasi yang berbeda pula. Kesemuanya itu menerangkan bahwa kinerja pada dasarnya dipengaruhi oleh beberapa faktor diantaranya 
BEduManageRs Journal

Borneo Educational Management and Research Journal, Vol.2, No.1, 2021

ISSN: 2747-0504

kepemimpinan, motivasi, maupun budaya organisasi.

Begitu pentingnya peran SDM dalam menentukan keberhasilan perusahaan, maka organisasi harus mampu mewujudkan keinginan dan kebutuhan karyawan melalui pemberian motivasi sehingga dapat mencapai kinerja yang tinggi. Setiap manajer perlu memprediksi adanya usaha pengembangan keterampilan dan kemampuan manajerial untuk memberikan motivasi kepada bawahannya. Manajer memiliki tanggung jawab dalam membantu dan mempengaruhi tingkah laku bawahannya agar mereka dapat melaksanakan tugas secara efektif dan efisien. Dengan demikian keberhasilan manajer memotivasi bawahannya tergantung pada bagaimana manajer memahami motif para karyawannya. Dalam hal ini, perusahaan bukan saja mengharapkan karyawan mampu, cakap dan terampil, tetapi yang terpenting mereka mau bekerja giat dan berkeinginan untuk mencapai hasil kinerja yang maksimal (Hasibuan, 2007:13).

Pengukuran kinerja merupakan suatu hal penting bagi organisasi baik yang bersifat profit maupun non profit. Ini dikarenakan pengukuran kinerja dapat digunakan untuk menilai keberhasilan suatu perusahaan. Selain itu juga dapat dipergunakan untuk melakukan penyusunan strategi-strategi bisnis yang cocok dan dapat dijadikan sebagai dasar dalam penyusunan sistem manajemen yang lebih baik.

Salah satu permasalahan yang dihadapi oleh Fakultas Keguruan dan Ilmu Pendidikan saat ini adalah terjadinya penurunan kinerja pegawai. Tinggi rendahnya kinerja pegawai ternyata dipengaruhi oleh banyak faktor kepemimpinan, motivasi dan budaya organisasi. Guna lebih meningkatkan kinerja dapat diusahakan melalui pemberian motivasi dengan melihat kebutuhan yang dominan dari para pegawai, baik kebutuhan fisiologis ataupun kebutuhan-kebutuhan lain, serta kebutuhan aktualisasi diri. Oleh sebab itu, upaya untuk menjaga dan meningkatkan kinerja adalah hal yang mutlak dilakukan dalam rangka mewujudkan tujuan organisasi tersebut. Kinerja yang rendah akan berimplikasi kepada tidak tercapainya tujuan organisasi.

Banyak hal yang dapat mempengaruhi kinerja, untuk itu organisasi harus berusaha menjamin agar variabel-variabel yang berkaitan dengan kinerja pegawai dapat terpenuhi secara maksimal. Variabel-variabel tersebut antara lain kepemimpinan, motivasi dan budaya organisasi. Kedudukan pemimpin dalam suatu organisasi sangatlah penting dalam usaha untuk mencapai tujuan organisasi. Berhasil atau gagalnya suatu organisasi dalam mengemban misinya untuk mencapai tujuan, sebagian besar ditentukan oleh mutu kepemimpinan yang dijalankan oleh orang-orang yang diserahi tugas-tugas kepemimpinan dalam organisasi tersebut. Kepemimpinan akan membangun komitmen dan antusiasme yang diperlukan orang untuk menerapkan bakat mereka sepenuhnya guna membantu menyelesaikan rencana dan pengendalian yang tidak lain adalah memastikan segala sesuatunya berubah semestinya.

\section{KAJIAN TEORI}

1. Perilaku Kepemimpinan $\left(\mathrm{X}_{1}\right)$ adalah suatu kegiatan atau aktivitas pimpinan sehingga dapat menimbulkan kepatuhan, rasa hormat, loyalitas, dan kerjasama dari pegawainya. Indikator yang digunakan untuk mengukur kepemimpinan, yakni :

a. Konsiderasi adalah kepemimpinan yang cenderung kearah kepentingan bawahan, meliputi : 
BEduManageRs Journal

Borneo Educational Management and Research Journal, Vol.2, No.1, 2021

ISSN: 2747-0504

1) Ramah tamah terhadap karyawan sehingga tidak terkesan angkuh dan sombong.

2) Mendukung dan membela bawahan apabila bawahan menunjukkan prestasi kerja yang memuaskan.

3) Bersedia berkonsultasi dengan bawahan dalam menghadapi permasalahan dalam pekerjaan.

4) Bersedia mendengarkan bawahan sebagai salah satu bentuk kepedulian pimpinan terhadap segala keluh kesah bawahan.

5) Bersedia menerima usulan bawahan untuk kelancaran pekerjaan dan sebagai bentuk penghargaan terhadap bawahan.

6) Memikirkan kesejahteraan karyawan sebagai bentuk tanggung jawab pemimpin dalam meningkatkan kinerja bawahan.

7) Memperlakukan bawahan setingkat dirinya sehingga tidak terkesan terdapat perbedaan yang mencolok antara pimpinan dan bawahan.

b. Struktur inisiasi adalah kepemimpinan yang cenderung lebih mementingkan tujuan organisasi daripada memperhatikan bawahan, yakni meliputi :

1) Memberikan kritik terhadap pelaksanaan pekerjaan yang tidak sempurna.

2) Menekankan pentingnya batas waktu pelaksanaan tugas-tugas kepada bawahan.

3) Selalu memberitahu hal-hal yang harus dikerjakan bawahan.

4) Selalu memberi petunjuk kepada bawahan bagaimana melakukan tugasnya.
5) Memberikan petunjuk dan arahan kepada bawahan bagaimana melaksanakan tugas dengan baik.

6) Memberikan standar tertentu atas pelaksanaan pekerjaan.

7) Meminta kepada bawahan agar selalu menuruti dan mengikuti standar yang telah ditetapkan.

8) Selalu melakukan pengawasan apakah bawahan bekerja dengan penuh kemampuan.

2. Motivasi Kerja $\left(\mathrm{X}_{2}\right)$ adalah merupakan tindakan yang dilakukan pimpinan untuk mendorong pegawainya agar dapat melakukan pekerjaan semaksimal mungkin sehingga tujuan yang telah ditetapkan dapat tercapai. Indikator yang dapat digunakan untuk mengukur motivasi meliputi :

a. Kebutuhan akan eksistensi (existence needs) adalah kebutuhan pegawai yang berhubungan dengan penggajian, tunjangan, dan kondisi kerja yang aman dan nyaman termasuk didalamnya physiological needs dan safety needs. Indikator kebutuhan akan eksistensi meliputi :

1) Penggajian.

2) Tunjangan.

3) Kondisi kerja yang aman dan nyaman.

4) Adanya jaminan sosial tenaga kerja.

b. Kebutuhan akan persaudaraan (relationship) adalah kebutuhan pegawai yang berhubungan dengan memiliki dan dapat mengadakan hubungan sosial dan keanggotaan kelompok yang melibatkan wakil pekerja, supervisor, bahkan keluarga serta teman. Kebutuhan ini berkaitan dengan social needs dan esteem needs. Indikator kebutuhan akan persaudaraan ini meliputi : 
BEduManageRs Journal

Borneo Educational Management and Research Journal, Vol.2, No.1, 2021

ISSN: 2747-0504

1) Memiliki serikat pekerja.

2) Adanya pengakuan atas serikat pekerja.

3) Adanya kesempatan untuk mengembangkan diri.

4) Adanya kesempatan untuk meningkatkan kemandirian.

5) Adanya kesempatan untuk meraih kebebasan.

c. Kebutuhan akan pertumbuhan (growth) adalah kebutuhan pegawai yang berhubungan dengan pengembangan pegawai, karir pegawai, dan dapat melakukan pekerjaan yang kreatif maupun aktivitas non kerja. Indikator kebutuhan akan pertumbuhan meliputi :

1) Adanya kesempatan untuk pengembangan sumber daya manusia pegawai.

2) Adanya kesempatan untuk pengembangan karir.

3) Adanya kesempatan untuk pengembangan kreatifitas pegawai.

3. Pendidikan $\left(X_{3}\right)$ adalah suatu proses, tekhnik, dan metode belajar mengajar dengan maksud mentransfer suatu pengetahuan dari seseorang kepada orang lain melalui prosedur yang sistematis dan terorganisir yang berlangsung dalam jangka waktu yang relatif lama untuk mengembangkan potensi dirinya untuk memiliki kekuatan spiritual keagamaan, pengendalian diri, kepribadian, kecerdasan, akhlak mulia, serta keterampilan yang diperlukan dirinya, masyarakat, bangsa dan Negara. Indikator yang digunakan :

a. Pendidikan dasar ; jenjang pendidikan awal selama 9 tahun pertama masa sekolah anak-anak yang melandasi jenjang pendidikan menengah.

b. Pendidikan menengah ; jenjang pendidikan lanjutan pendidikan dasar. c. Pendidikan tinggi ; jenjang pendidikan setelah pendidikan menengah yang mencakup program sarjana, magister, doktor, dan spesialis yang diselenggarakan oleh perguruan tinggi

4. Kinerja Pegawai (Y) adalah suatu hasil yang dicapai pegawai dalam melaksanakan tugas menurut ukuran yang ditetapkan untuk pekerjaan pegawai yang bersangkutan, yang meliputi kualitas kerja dan disiplin kerja. Indikator yang digunakan meliputi :

a. Pekerjaan yang dapat diselesaikan setiap harinya (quantity of work).

b. Pekerjaan yang sudah memenuhi kualitas yang diinginkan (quality of work).

c. Memiliki kemampuan dan keterampilan yang sesuai untuk bidang pekerjaannya (job knowledge).

d. Memiliki kreatifitas untuk menyelesaikan dan memecahkan persoalan yang dihadapi dalam pekerjaan (creativeness).

e. Kesediaan untuk bekerja sama dengan orang lain/sesama anggota organisasi (cooperation).

f. Kesadaran berdisiplin dan dapat dipercaya dalam kehadiran dan penyelesaian pekerjaan (dependability).

g. Semangat untuk melaksanakan tugastugas baru dan dalam memperbesar tanggung jawab (initiative).

h. Aspek yang menyangkut kepribadian, kepemimpinan, keramahtamahan dan integritas pribadi (personal qualities).

\section{METODE PENELITIAN}

Metode kuantitatif merupakan salah satu jenis penelitian yang spesifikasinya adalah sistematis, terencana, dan terstruktur dengan jelas sejak awal hingga pembuatan desain 
BEduManageRs Journal

Borneo Educational Management and Research Journal, Vol.2, No.1, 2021

ISSN: 2747-0504

penelitiannya. Definisi lain menyebutkan penelitian kuantitatif adalah penelitian yang banyak menuntut penggunaan angka, mulai dari pengumpulan data, penafsiran terhadap data tersebut, serta penampilan dari hasilnya. Demikian pula pada tahap kesimpulan penelitian akan lebih baik bila disertai dengan gambar, tabel, grafik, atau tampilan lainnya.

Menurut Sugiyono, metode penelitian kuantitatif dapat diartikan sebagai metode penelitian yang berlandaskan pada filsafat positivisme, digunakan untuk meneliti pada populasi atau sampel tertentu. Teknik engambilan sampel pada umumnya dilakukan secara random, pengumpulan data menggunakan instrumen penelitian, analisis data bersifat kuantitatif/statistik dengan tujuan untuk menguji hipotesis yang telah ditetapkan (Sugiyono, 2012:7).

Metode kuantitatif sering juga disebut metode tradisional, positivistik, ilmiah (scientific) dan metode discovery. Metode kuantitatif dinamakan metode tradisional, karena metode ini sudah cukup lama digunakan sehingga sudah mentradisi sebagai metode untuk penelitian. Metode ini disebut sebagai metode positivistik karena berlandaskan pada filsafat positivisme. Metode ini disebut sebagai metode ilmiah (scientific) karena metode ini telah memenuhi kaidah-kaidah ilmiah yaitu konkrit, empiris, obyektif, terukur, rasional dan sistematis. Metode ini juga disebut metode discovery karena dengan metode ini dapat ditemukan dan dikembangkan berbagai iptek baru.

Metode ini disebut metode kuantitatif karena data penelitian berupa angka-angka dan analisis menggunakan statistik. Penelitian kuantitatif merupakan studi yang diposisikan sebagai bebas nilai (value free). Dengan kata lain, penelitian kuantitatif sangat ketat menerapkan prinsip-prinsip obyektivitas. Obyektivitas itu diperoleh antara lain melalui penggunaan instrumen yang telãh diuji validitas dan reliabilitasnya. Peneliti yang melakukan studi kuantitatif mereduksi sedemikian rupa hal-hal yang dapat membuat bias, misalnya akibat masuknya persepsi dan nilai-nilai pribadi. Jika dalam penelaahan muncul adanya bias itu maka penelitian kuantitatif akan jauh dari kaidah-kaidah teknik ilmiah yang sesungguhnya (Danim, Sudarwan, 2002:35).

\section{HASIL DAN PEMBAHASAN}

Berdasarkan hasil penelitian diketahui persamaan regeresi linier berganda variabel Kepemimpinan $\left(\mathrm{X}_{1}\right)$, Motivasi Kerja $\left(\mathrm{X}_{2}\right)$, dan Pendidikan $\left(\mathrm{X}_{3}\right)$ terhadap Kinerja $(\mathrm{Y})$ pegawai Fakultas Keguruan dan Ilmu Pendidikan Universitas Mulawarman dapat diperoleh persamaan regresi :

$Y=4,166+0,171 X_{1}+\mathbf{0 , 1 4 7} X_{2}+\mathbf{0 , 1 6 8} X_{3}$

Nilai $F_{\text {hitung }}$ sebesar 0,801 lebih dari $F$ tabel $=3,39$ dengan signifikansi 0,000 lebih kecil dari $\alpha$ 5\%. Artinya secara simultan variabel Kepemimpinan $\left(\mathrm{X}_{1}\right)$, Motivasi Kerja $\left(\mathrm{X}_{2}\right)$ dan Pendidikan $\left(\mathrm{X}_{3}\right)$ berpengaruh secara simultan (bersama-sama) terhadap Kinerja (Y) pegawai Fakultas Keguruan dan Ilmu Pendidikan Universitas Mulawarman. Sehingga berdasarkan hasil pembuktian tersebut maka menolak Ho dan menerima $\mathrm{Ha}$, yang artinya ada pengaruh signifikan secara simultan dari variabel Kepemimpinan $\left(\mathrm{X}_{1}\right)$, Motivasi Kerja $\left(\mathrm{X}_{2}\right)$ dan Pendidikan $\left(\mathrm{X}_{3}\right)$ terhadap Kinerja (Y) pegawai Fakultas Keguruan dan Ilmu Pendidikan Universitas Mulawarman.

Hasil uji parsial menunjukkan bahwa uji t untuk Kepemimpinan $\left(\mathrm{X}_{1}\right)$ terhadap Kinerja (Y) dengan nilai $\mathrm{t}$ hitung sebesar 1,580 lebih kecil dari $\mathrm{t}$ tabel 2,060 atau signifikansi $\mathrm{t}=$ 0,000 lebih kecil daripada $\alpha 5 \%$, menunjukkan variabel Kepemimpinan $\left(\mathrm{X}_{1}\right)$ berpengaruh signifikan terhadap Kinerja (Y). 
BEduManageRs Journal

Borneo Educational Management and Research Journal, Vol.2, No.1, 2021

ISSN: 2747-0504

Uji t untuk Motivasi Kerja $\left(\mathrm{X}_{2}\right)$ terhadap Kinerja (Y), dengan nilai $t_{\text {hitung }}$ sebesar 1,660 lebih kecil dari $\mathrm{t}_{\text {tabel }}=2,060$ atau signifikansi $\mathrm{t}=1,660$ lebih kecil daripada $\alpha 5 \%$, menunjukkan bahwa variabel Motivasi Kerja $\left(\mathrm{X}_{2}\right)$ berpengaruh signifikan terhadap Kinerja $(\mathrm{Y})$. Uji t untuk Pendidikan $\left(\mathrm{X}_{3}\right)$ terhadap Kinerja (Y), dengan nilai $t_{\text {hitung }}$ sebesar 1,664 lebih kecil dari $\mathrm{t}_{\text {tabel }}=2,060$ atau signifikansi $\mathrm{t}=1,664$ lebih kecil daripada $\alpha 5 \%$, menunjukkan bahwa variabel Pendidikan $\left(\mathrm{X}_{3}\right)$ berpengaruh signifikan terhadap Kinerja (Y).

Nilai koefisien regresi linier berganda keseluruhan variabel adalah positif, sehingga apabila terdapat tiga variabel bebas atau lebih (Kepemimpinan, Motivasi Kerja dan Pendidikan) meningkat atau ditingkatkan maka akan berpengaruh signifikan terhadap kinerja pegawai Fakultas Keguruan dan Ilmu Pendidikan Universitas Mulawarman dengan cara melakukan pemeriksaan internal tentang pekerjaan pegawai/karyawan melalui berkasberkas atau kertas kerja apakah sudah dilakukan dengan baik atau belum, pengamatan yang dilakukan oleh pimpinan kepada bawahan secara langsung dengan tujuan untuk melihat apakah bawahan telah bekerja dengan baik, dan laporan tentang kegiatan/tugas yang diberikan oleh pimpinan apakah sudah dilaksanakan oleh bawahan dengan baik, dapat juga melalui laporan yang disampaikan bawahan tentang pekerjaannya secara lisan dengan berbicara langsung kepada pimpinan yang frekuensinya tergantung pada kebiasaan yang berlaku di Fakultas Keguruan dan Ilmu Pendidikan Universitas Mulawarman dan laporan tertulis adalah memberikan laporan hasil pekerjaan kepada pimpinan pengamatan yang dibuat bawahan tentang hasil pekerjaannya secara tertulis.

Menurut Miftah Thoha (2008:288), sifatsifat kepemimpinan yang melekat pada diri pegawai yang nampaknya mempunyai pengaruh terhadap keberhasilan kepemimpinan organisasi adalah :

1. Kecerdasan; hasil penelitian membuktikan bahwa pemimpin mempunyai tingkat kecerdasan yang lebih tinggi dibandingkan dengan yang dipimpin.

2. Kedewasaan dan keluasan hubungan sosial ; pemimpin cenderung menjadi matang dan mempunyai emosi yang stabil serta mempunyai perhatian yang luas terhadap aktivitas-aktivitas sosial.

3. Motivasi diri dan dorongan berprestasi ; para pemimpin secara relatif mempunyai dorongan motivasi yang kuat untuk berprestasi.

4. Sikap-sikap hubungan kemanusiaan ; pemimpin-pemimpin yang berhasil mau mengakui harga diri dan kehormatan para pengikutnya dan mampu berpihak kepadanya.

Berdasarkan output statistik pengaruh motivasi kerja terhadap produktivitas kinerja pegawai Fakultas Keguruan dan Ilmu Pendidikan Universitas Mulawarman diatas menujukan bahwa motivasi berpengaruh dan signifikan terhadap produktivitas kinerja pegawai Fakultas Keguruan dan Ilmu Pendidikan Universitas Mulawarman, hal ini menunjukan bahwa semakin tinggi motivasi pegawai untuk bekerja maka semakin tinggi tingkat produktivitas kinerja pegawai Fakultas Keguruan dan Ilmu Pendidikan Universitas Mulawarman.

Latar belakang pendidikan, motivasi dan minat secara bersama-sama berpengaruh positif dan signifikan terhadap produktivitas kinerja pegawai Fakultas Keguruan dan Ilmu Pendidikan Universitas Mulawarman. Hal ini berarti bahwa variabel latar belakang pendidikan memberikan pengaruh positif maka akan diikuti pengaruh positif dari variabel motivasi dan minat karyawan, begitu 
BEduManageRs Journal

Borneo Educational Management and Research Journal, Vol.2, No.1, 2021

ISSN: 2747-0504

juga sebalikanya. Jadi jika latar belakang pendidikan meningkat maka motivasi dan minat karyawan meningkat. Berdasarkan hasil pengujian data menunjukan terdapat pengaruh yang signifikan antara perilaku kepemimpinan, pendidikan dan motivasi kerja. Hasil penelitian ini juga menyatakan bahwa tingkat pendidikan mempunyai pengaruh yang signifikan terhadap produktifitas kinerja.

Berdasarkan hasil penelitian dan analisis terhadap variabel-variabel yang mempengaruhi variabel Kepemimpinan $\left(\mathrm{X}_{1}\right)$ berpengaruh secara signifikan terhadap Kinerja (Y) pegawai Fakultas Keguruan dan Ilmu Pendidikan Universitas Mulawarman. Hasil uji parsial menunjukkan bahwa uji t untuk variabel Kepemimpinan $\left(\mathrm{X}_{1}\right)$ terhadap Kinerja ( $\mathrm{Y}$ ) dengan nilai $\mathrm{t}_{\text {hitung }}$ sebesar 1,668 lebih kecil dari $t_{\text {tabel }} 0,260$ atau signifikansi $t$ $=1,668$ lebih kecil daripada $\alpha 5 \%$. Hal ini berarti bahwa variabel variabel Kepemimpinan $\left(\mathrm{X}_{1}\right)$ memiliki pengaruh signifikan terhadap Kinerja (Y) pegawai Fakultas Keguruan dan Ilmu Pendidikan Universitas Mulawarman sehinga hipotesis dalam penelitian ini diterima. Hal ini mengindikasikan bahwa kepemimpinan merupakan salah satu cara yang digunakan oleh seorang pimpinan untuk melakukan pengendalian.

\section{KESIMPULAN}

Berdasarkan hasil penelitian dan analisis data maka dapat ditarik simpulan sebagai berikut :

1. Variabel-variabel yang mempengaruhi variabel Kepemimpinan $\left(\mathrm{X}_{1}\right)$ berpengaruh secara signifikan terhadap Kinerja (Y) pegawai Fakultas Keguruan dan Ilmu Pendidikan Universitas Mulawarman. Hasil uji parsial menunjukkan bahwa uji $\mathrm{t}$ untuk variabel Kepemimpinan $\left(\mathrm{X}_{1}\right)$ terhadap Kinerja $(\mathrm{Y})$ dengan nilai $\mathrm{t}$ hitung sebesar 1,668 lebih kecil dari $t_{\text {tabel }} 0,260$ atau signifikansi $\mathrm{t}=1,668$ lebih kecil daripada $\alpha 5 \%$. Hal ini berarti bahwa variabel variabel Kepemimpinan $\left(\mathrm{X}_{1}\right)$ memiliki pengaruh signifikan terhadap Kinerja (Y) pegawai Fakultas Keguruan dan Ilmu Pendidikan Universitas Mulawarman sehinga hipotesis dalam penelitian ini diterima. Hal ini mengindikasikan bahwa kepemimpinan merupakan salah satu cara yang digunakan oleh seorang pimpinan untuk melakukan pengendalian.

2. Variabel motivasi kerja terhadap produktivitas kinerja pegawai Fakultas Keguruan dan Ilmu Pendidikan Universitas Mulawarman diatas menujukan bahwa motivasi berpengaruh dan signifikan terhadap produktivitas kinerja pegawai Fakultas Keguruan dan Ilmu Pendidikan Universitas Mulawarman, hal ini menunjukan bahwa semakin tinggi motivasi pegawai untuk bekerja maka semakin tinggi tingkat produktivitas kinerja pegawai Fakultas Keguruan dan Ilmu Pendidikan Universitas Mulawarman.

3. Variabel pendidikan berpengaruh positif dan signifikan terhadap kinerja pegawai. Hasil penelitian ini menunjukan adanya hubungan positif antara pendidikan dengan kinerja pegawai Fakultas Keguruan dan Ilmu Pendidikan Universitas Mulawarman. Hal ini berarti bahwa semakin baik tingkat latar belakang pendidikan maka semakin besar pula tingkat produktivitas kinerja pegawai Fakultas Keguruan dan Ilmu Pendidikan Universitas Mulawarman. yang dapat disimpulkan bahwa latar belakang pendidikan berpengaruh positif dan signifikan terhadap produktivitas kinerja.

4. Variabel Kepemimpinan $\left(\mathrm{X}_{1}\right)$ berpengaruh dominan terhadap Kinerja (Y) pegawai 
BEduManageRs Journal

Borneo Educational Management and Research Journal, Vol.2, No.1, 2021

ISSN: 2747-0504

Fakultas Keguruan dan Ilmu Pendidikan Universitas Mulawarman, sehingga secara universal hipotesis dalam penelitian ini diterima.

5. Dapat disimpulka bahwa $X_{1}, X_{2}$ signifikan terhadap Y (Kinerja Pegawai Fakultas Keguruan dan Ilmu Pendidikan ) dan $\mathrm{X}_{3}$ (Pendidikan) berpengaruh signifikan terhadap $\mathrm{X}_{1}, \mathrm{X}_{2}$, dan $\mathrm{Y}$.

\section{DAFTAR PUSTAKA}

Anderson, J.E., 1978. Public Policy Making, Hold Rinehart and Winston, New York.

Gomes, Faustino Cardoso. 2000. Manajemen Sumber Daya Manusia, Andi Offset, Yogyakarta.

Handayaningrat, H., 2006. Penilaian Kinerja dan Pengembangan Karyawan, BPFE UGM, Yogyakarta

Handoko, Hani. 2000. Manajemen Personalia dan Sumber Daya Manusia, Edisi Kedua, Penerbit BPFE-UGM, Yogyakarta.

Hasibuan, Malayu S. P. 1997. Manajemen Sumber Daya Manusia, Bumi Aksara, Jakarta.

Islamy, M. Irfan, 1997. Prinsip-prinsip Perumusan Kebijaksanaan Negara, Bumi Aksara, Jakarta

Kartono, 1998. Kepemimpinan dan Motivasi, Cetakan Kelima. Ghalia Indonesia, Jakarta.

Miftah, Thoha, 2004. Perilaku Organisasi Konsep Dasar dan Aplikasinya, Cetakan Kelima, Rajawali Grafindo, Jakarta

Miftha, Thoha, 2007. Manajemen Kepegawaian Sipil Di Indonesia, Kencana, Jakarta

Mangkunegara, A. P., 2007. Evaluasi Kinerja Sumber Daya Manusia, Refika Aditama, Bandung.
Mulyadi, 2001. Akuntansi Manajemen: Konsep, Manfaat, dan Rekayasa, Edisi Ke3, Salemba Empat, Jakarta.

Primajaya, Deni, 2013. Pengaruh Kepemimpinan Dan Motivasi Kerja Terhadap Kinerja Karyawan Pada PT Pertamina (Persero) UPMS IV Semarang. Tesis. Program Magister Ilmu Administrasi Universitas Diponegoro Semarang

Rivai, Veithzal dan Jauvani Sagala, E., 2004. Manajemen Sumber Daya Manusia untuk Perusahaan. Rajawali Pers, Jakarta.

Robbins, Stephen P dan Coulter, Mary. 2006. Manajemen Edisi Kesepuluh Jilid 2. Erlangga, Jakarta.

Santoso, H. B. 2002. Analisis Pengaruh Perilaku Kepemimpinan dan Faktor Motivasi Terhadap Prestasi Kerja Karyawan PT. Mekar Armada Jaya Kabupaten Magelang. Tesis. Program Pascasarjana Universitas Diponegoro Semarang.

Sardiman. 2006. Manajemen Kepemimpinan. Cetakan Ketiga, Raja Grafindo Persada, Jakarta.

Siagian, Sondang P, 2003. Teori Motivasi dan Aplikasinya. Rineka Cipta, Jakarta

Sinungan, 2003. Budaya Produktif. Edisi Revisi, Rajawali Grafindo, Jakarta

Singarimbun dan M. Effendi S., 1986. Metode Penelitian Survei, LP3ES, Jakarta.

Soedjono, 2005. Pengukuran Kinerja Karyawan, Cetakan Ketujuh, Rineka Cipta, Jakarta.

Sugiyono, 2012. Metode Penelitian Bisnis (Pendekatan Kuantitatif, Kualitatif, dan $R \& D)$, Alfabetha, Bandung.

Stooner, James A.F, R. E, Freeman, R. Edward dan Daniel R. Gilbert JR, 1996. Manajemen, Prenhallindo, Jakarta.

Umar, Husein. 2005. Riset Sumber Daya Manusia Dalam Organisasi. Gramedia Pustaka Utama, Jakarta. 